\title{
Reserve Selection Based on Vegetation in the Brazilian Atlantic Forest
}

\author{
Carlos Eduardo Viveiros Grelle ${ }^{1, \star}$, Maria Lucia Lorini²,3 \& Míriam Plaza Pinto ${ }^{3}$
}

\author{
${ }^{1}$ Laboratório de Vertebrados, Departamento de Ecologia, Universidade Federal do Rio de Janeiro - UFRJ, \\ CP 68020, CEP 21941-590, Rio de Janeiro, RJ, Brasil \\ ${ }^{2}$ Laboratório de Gestão da Biodiversidade, Departamento de Botânica, Universidade Federal do Rio de Janeiro - UFRJ, \\ CP 68029, CEP 21941-971, Rio de Janeiro, RJ, Brasil \\ ${ }_{3}^{3}$ Programa de Pós-Graduação em Ecologia, Laboratório de Vertebrados, Departamento de Ecologia, \\ Universidade Federal do Rio de Janeiro - UFRJ, CP 68020, CEP 21941-590, Rio de Janeiro, RJ, Brasil
}

\begin{abstract}
Brazilian Atlantic Forest is recognized as a hottest hotspot of biodiversity, and plant endemism is a key criterion used to this definition. In this biome, although geographic range of most plant species is unknown, it is possible to define limits of vegetation types. Here we performed a reserve selection analysis using vegetation types for Brazilian Atlantic Forest, more specifically in Rio de Janeiro State. The area of 19 vegetation types was calculated in each of the $5 \mathrm{~km} \times 5$ cells $\mathrm{km}$ superimposed to the Rio de Janeiro State. The representation targets established in the reserve selection procedure was $30 \%$ of the total area for more common vegetation types, and a higher target was established for rare vegetation types. The final network that represents all the targets for vegetation types with the smaller possible number of cells contains 351 cells. Many cells selected are coincident with current strictly protected areas, but this study shows the urgency to increase the number of protected areas mainly in the North and Northeast regions of Rio de Janeiro State. Twenty three cells are coincident with priority areas indicated to be created as strictly use reserves by a government agency. However, there are several important cells selected in our analysis that are not covered by the actual strictly reserves system. Four vegetation types are not represented in the current strict use reserve system. Further analyses based on vegetation could be blended with scattered data of species geographic distribution to obtain more comprehensive results and strategies.
\end{abstract}

Key words: Complementarity, Conservation Planning, Rio de Janeiro State, Protected Areas.

\section{Introduction}

What to protect? This emblematic question launched years ago (Margules \& Pressey 2000; Vane-Wright et al.1991) persist and it is hard to answer. As a multidisciplinar area, Conservation Biology has many goals and approaches to conservation planning. What are the best targets or biodiversity information to work is an open question and theme for intense debates (see Pressey \& Bottrill 2009 and references therein for a recent discussion on this theme). However, a unifying point is that resources destined to conservation are limited, and should be used to minimize the reduction of natural areas and the loss of species and ecosystem services. Therefore, principles of systematic conservation planning should be used, including reserve

*Send correspondence to: Carlos Eduardo Viveiros Grelle Laboratório de Vertebrados, Departamento de Ecologia, Universidade Federal do Rio de Janeiro - UFRJ,

CP 68020, CEP 21941-590, Rio de Janeiro, RJ, Brasil

E-mail: grellece@biologia.ufrj.br selection (Margules \& Pressey 2000). This planning is urgent in regions with many endemic species, and under a high pressure of habitat reduction and fragmentation.

Brazilian Atlantic Forest (BAF) is recognized as a hottest hotspot of biodiversity (Myers et al. 2000) and it is a matter of many published articles on population viability (e.g. Brito \& Grelle 2004, 2006), effects of habitat reduction (e.g. Brooks et al. 1999; Grelle et al. 1999, 2005) and effects of habitat fragmentation (e.g. Chiarello 1999; Pires et al. 2002; Pardini et al. 2005; Metzger et al. 2009; Vieira et al. 2009). This biome has more articles on Conservation Biology than any other Brazilian biome (Grelle et al. 2009). However, besides scientific knowledge and the many initiatives for conservation (e.g. Galindo-Leal \& Câmara 2003; Rocha et al. 2006) articles on conservation planning is lacking. Only gap analyis performed (Paglia et al. 2004; Vicente et al. 2009) are not suficient to answers the questions for conservation planning. Thus, there is not synthesis for this biome, except a recent study of reserve selection with endemic primates 
(Pinto \& Grelle 2009a). It is important to note that in Brazil there are some governmental and NGOs (non-governmental organizations) conservation planning works used to guide conservation actions (Brasil 2007), although they are not published in scientific journals.

Regarding data availability, for many tropical regions Linnean and Wallacean shortfalls could preclude further analyses using species data. In Brazilian Atlantic Forest our knowledge about taxonomic and distributional range is limited to vertebrate species (see Silva \& Casteletti 2003). We don't know the geographic range of plants, but we know the limits of vegetation types. This question is not new, and an alternative is to run analysis based on landscape structure parameters (Lindenmayer et al. 2008) such as vegetation. Here we performed a reserve selection analysis using vegetation types for Brazilian Atlantic Forest, specifically in Rio de Janeiro State. Currently BAF presents between 11.4 to $16 \%$ of original forest cover, severely fragmented in small remnants (Ribeiro et al. 2009), where only $2 \%$ is under strictly protected areas (Pinto et al. 2006). Originally, the Rio de Janeiro State had a total cover of Atlantic Forest vegetation types, which is now restricted to about $20 \%$. The current strictly protected area network sums 272.745 ha, and inside these reserves $77 \%$ are vegetated areas (Fidalgo et al. 2009). In addition, this reserve system, that represents only about $6 \%$ of Rio de Janeiro original vegetation, seems not to be well distributed among the vegetation types.

The reserve selection approach applied in this study is based on the complementarity concept. Reserve selection problems are actually solved using algorithms based on the complementarity concept (Margules \& Pressey 2000; Margules et al. 1988; Kirkpatrick 1983). Complementarity is a measure of the relative contribution of an area to the meet the representation targets of biodiversity elements (considered in the study) not yet completely represented in a network (Margules \& Pressey 2000; Pressey et al. 1993). An area has a high complementarity value when it has a lot of elements not included in other areas already selected. So, this concept is directly related to the beta diversity concept or turnover in the spatial diversity.

\section{Material and Methods}

Vegetation cover data were based on Brazilian Atlantic Forest Biome remnant vegetation map produced by the Brazilian Ministry of the Environment - MMA (Cruz et al. 2007, downloaded from www.mma.gov.br, accessed on 2008). This map was constructed by an object-based image analysis and supervised classification based mostly on TM/Landsat-5, reference year 2002. The mapping scale presents a meso-scale detail $(1: 250,000)$ in vector format. This land cover map depicts classes representing vegetated (vegetation types) and non-vegetated (e.g. urban, pasture, agricultural, silvicultural, rocky outcrops, dunes) covers. In this study only the vegetated classes were considered and the classification of vegetation types was based on IBGE classification system for Brazilian vegetation (Veloso et al. 1992). Individual maps were produced for each vegetation type at a regional scale, clipped by the geographical extent of the Rio de Janeiro State.

A grid formed by cells with $5 \times 5 \mathrm{~km}$ of spatial resolution was superimposed to the State of Rio de Janeiro. Because some cells are not entirely filled with the area of the state (those on the edge of the state), only the cells with at least $25 \%$ of its area filled with the Rio de Janeiro State were kept in the grid. The final grid contained 2,306 cells. These cells are our units of analysis, in which all data were organized.

The grid was superimposed to vegetation maps in order to calculate the area (hectares) occupied in each of 2,306 cells by each vegetation type. To assure accurate area calculation, the map of each vegetation type was previously projected to a cylindrical equal area projection under South America 1969 datum.

The reserve selection procedure was done using the simulated annealing algorithm, implemented through the software SITES (Andelman et al. 1999; Possingham et al. 2000, 2006). The algorithm was runned 200 times with 10,000,000 iterations. This algorithm is based on the complementarity concept. It works first selecting a network of random cells, than it proceeds adding, excluding or just changing cells randomly and computing the cost function at each iteration (Andelman et al. 1999). This guarantees that it will find the network with the smaller possible number of cells that can represent all the targets stated (Possingham et al. 2006). The targets can be stated for each component of the biodiversity being analysed.

Since we used abundance (area occupied in the cell) data for 19 vegetation types in this study, different targets were stated for each of them. For those vegetation types that have a larger total area in the state (more than 3,000 ha), our target was to represent at least $30 \%$ of its total area. This threshold was chosen because above 30\% of habitat cover the spatial configuration of remnants is expected to play a minor role than the total habitat area for biodiversity persistence in the landscapes (Andrén 1994). Besides, as the remnant vegetation cover in Brazilian Atlantic Forest Biome is highly reduced and fragmented, a threshold below $30 \%$ could result in a very low habitat area target. For the vegetation types with total area between 2,000 and 3,000 ha, our target was to represent at least 1,000 ha (if we used 30\% as target, the minimum area to be represent would be too small). And for the vegetation types that have a smaller total area than 700 ha, our target was to represent all of it.

Protected areas data (only strictly protected areas - similar of categories I-IV of IUCN) were downloaded from www.ibama.gov.br, accessed on 2008. Prioritary areas data (Brasil 2007) were downloaded from www.mma.gov.br, accessed on 2009. 


\section{Results}

There are 19 vegetation types that currently occur in the State of Rio de Janeiro, divided in six main vegetation classes, grouping several physiognomically and floristically distinct types: 1) evergreen forests; 2) semi-deciduous forests; 3) pioneer formations, swamps, marshes, mangroves, and "restinga" (lowland vegetation on Quartenary sandy soils near the coast); 4) refuges, "campos de altitude" (highland herbaceous vegetation on rocky soils); 5) savanna; and 6) estepic savanna. All of them belong to the Brazilian Atlantic Forest Biome (Table 1).

The vegetation types with the widest distribution are the FODM (Floresta Ombrófila Densa Montana, Montane Evergreen Dense Forest), which occurs in 743 cells totalizing 496,223 ha, and FODSM (Floresta Ombrófila Densa Submontana, Submontane Evergreen Dense Forest), that occurs in 753 cells in an area of 359,639 ha. The smallest vegetation type distribution corresponds to SEGL (Savana Estépica Gramíneo-Lenhosa, Herbaceous-Arbustive Estepic Savanna), occupying only two cells in 168 ha. Another vegetation types with very restrict distribution are SEF
(Savana Estépica Florestada, Arboreous Estepic Savanna), and FESA (Floresta Estacional Semidecidual Aluvial, Aluvial Semi-deciduous Forest), with 487 and 463 ha in three and 21 cells, respectively. Two vegetation types have more than 200,000 ha and the most of them have less than 25,000 ha in area in the State of Rio de Janeiro, which generates a frequency distribution skewed to right (Figure 1).

The richness pattern of the vegetation types is presented in Figure 2a. There is not a clear and homogeneous spatial gradient, and the richest cells have a scatter distribution along the study region. However, there is a great cluster of rich cells located at the east region and another two small clusters in the south and southwest coasts. From the 2,306 grid cells, just nine cells are composed of six vegetation types and five cells contain five vegetation types. Cells with no vegetation types $(n=132)$ correspond to anthropic areas converted to urban, agriculture or pasture use. Poor cells result from a range of different situations. At one end, all the area of the cell is composed of just one type of vegetation. In the other end, a small portion of the cell is composed of one vegetation type, and most of it is converted to anthropic use.

Table 1. Vegetation type, number of grid cells and total occurrence area (hectares) of each vegetation type, area (hectares) of each vegetation type under Strictly Protected Areas, number of grid cells, represented area (hectares) of each vegetation type and proportion of the total area represented in the final solution.

\begin{tabular}{lcccccc}
\hline Vegetation & N. cells & Total area (ha) & Area under SPAs (ha) & N. repres. cells & Repres. area (ha) & \% repres. \\
\hline FODM & 743 & 496,223 & 129,716 & 150 & 148,874 & 30.00 \\
FODSM & 753 & 359,639 & 63,618 & 144 & 108,154 & 30.07 \\
FESM & 586 & 113,030 & 0 & 71 & 33,991 & 30.07 \\
FPIM & 201 & 104,964 & 14,632 & 26 & 31,552 & 30.06 \\
FESS & 803 & 101,406 & 1,811 & 71 & 30,593 & 30.17 \\
FODTB & 505 & 62,901 & 5,992 & 67 & 18,974 & 30.16 \\
FPIFM & 180 & 46,291 & 2,490 & 21 & 13,922 & 30.07 \\
FODAM & 91 & 23,002 & 15,923 & 17 & 7,367 & 32.03 \\
FPIFL & 151 & 16,759 & 801 & 16 & 5,217 & 31.13 \\
FESTB & 204 & 16,303 & 604 & 27 & 4,901 & 30.06 \\
FODA & 155 & 5,767 & 352 & 15 & 1,751 & 30.37 \\
RAM & 21 & 3,483 & 3,031 & 5 & 1,265 & 36.33 \\
SGL & 36 & 2,925 & 110 & 5 & 1,024 & 35.02 \\
SF & 59 & 2,166 & 35 & 6 & 1,103 & 50.90 \\
RM & 58 & 2,005 & 534 & 9 & 1,007 & 50.23 \\
RSM & 39 & 656 & 48 & 39 & 656 & 100.00 \\
SEF & 3 & 487 & 0 & 21 & 487 & 100.00 \\
FESA & 21 & 463 & 168 & 0 & 463 & 100.00 \\
SEGL & 2 & 54 & 2 & 168 & 100.00 \\
\hline
\end{tabular}

FODM: Montane Evergreen Dense Forest; FODSM: Submontane Evergreen Dense Forest; FESM: Montane Semi-deciduous Forest; FPIM: Pioneer Formation with Marine Influence, "restinga" vegetation; FESS: Submontane Semi-deciduous Forest; FODTB: Lowland Evergreen Dense Forest; FPIFM: Pioneer Formation with Fluviomarine Influence, mangroves and marshes; FODAM: High-Montane Evergreen Dense Forest; FPIFL: Pioneer Formation with Fluvial Influence, swamps; FESTB: Lowland Semi-deciduous Forest; FODA: Aluvial Evergreen Dense Forest; RAM: High-Montane Refuges, "campos de altitude" vegetation; SGL: Herbaceous-Arbustive Savanna; SF: Arboreous Savanna; RM: Montane Refuges, "campos de altitude” vegetation; RSM: Submontane Refuges, "campos de altitude" vegetation; SEF: Arboreous Estepic Savanna; FESA: Aluvial Semi-deciduous Forest; SEGL: Herbaceous-Arbustive Estepic Savanna. 


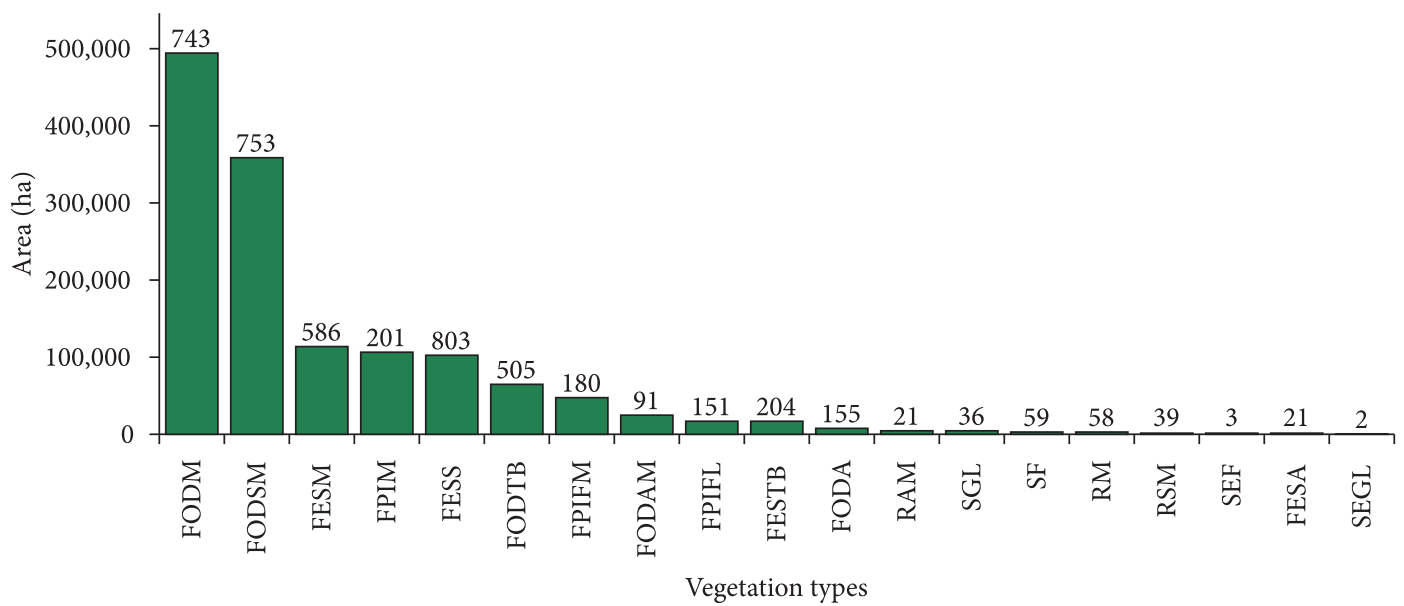

Figure 1. Area (vertical bars) and number of cells (numbers above the bars) of the different vegetation types that occur along the 2,306 grid cells along the State of Rio de Janeiro FODM: Montane Evergreen Dense Forest; FODSM: Submontane Evergreen Dense Forest; FESM: Montane Semi-deciduous Forest; FPIM: Pioneer Formation with Marine Influence, "restinga" vegetation; FESS: Submontane Semi-deciduous Forest; FODTB: Lowland Evergreen Dense Forest; FPIFM: Pioneer Formation with Fluviomarine Influence, mangroves and marshes; FODAM: High-Montane Evergreen Dense Forest; FPIFL: Pioneer Formation with Fluvial Influence, swamps; FESTB: Lowland Semi-deciduous Forest; FODA: Aluvial Evergreen Dense Forest; RAM: High-Montane Refuges, "campos de altitude" vegetation; SGL: Herbaceous-Arbustive Savanna; SF: Arboreous Savanna; RM: Montane Refuges, "campos de altitude" vegetation; RSM: Submontane Refuges, "campos de altitude" vegetation; SEF: Arboreous Estepic Savanna; FESA: Aluvial Semi-deciduous Forest; SEGL: Herbaceous-Arbustive Estepic Savanna.

There are few cells with the more restricted vegetation types (Figure $2 \mathrm{~b})$. Most of them $(\mathrm{n}=2,127)$ have no occurrence of these rare vegetation types. We considered restricted vegetation type those that occupy a total area smaller than 30,000 ha. According this cut level, seven vegetation types are signed as rare: SEGL (Savana Estépica Gramíneo-Lenhosa): Herbaceous-Arbustive Estepic Savanna; SEF (Savana Estépica Florestada): Arboreous Estepic Savanna; FESA (Floresta Estacional Semidecidual Aluvial): Aluvial Semi-deciduous Forest; RM (Refúgio Montano) Montane Refuges; RSM (Refúgio Submontano) Submontane Refuges; SF (Savana Florestada): Arboreous Savanna; and SGL (Savana Gramíneo-Lenhosa): Herbaceous-Arbustive Savanna. Only one cell has three different rare vegetation types and it is located at the east region of the state. This is the region where can be observed most of the rare grid cells. A total of 37 cells contain two rare vegetation types and 141 cells contain just one type, and they are sparsely distributed along the study region.

The final network that represents all vegetation types with the smaller possible number of cells contains 351 cells (Figure 3). This solution meets all the targets stated for each vegetation type (Table 1 ). The cells selected in the network have a scatter distribution along the study region, but there are two clusters of selected cells located in eastern and southwestern portions of the Rio de Janeiro State. The strictly protected areas that occur in this state generally include at least one area indicated as priority area in our network solution. However, there are several important cells selected in our analysis that are not covered by the actual strictly reserves system.

\section{Discussion}

The total territory of Rio de Janeiro State was originally covered by vegetation types of Brazilian Atlantic Forest. Nowadays, the remnants sum only a fifth of this coverage, located mainly in montane regions, surrounding by a matrix of anthropogenic areas converted to rural and urban use on more flat and accessible regions (see Vieira et al. 2009).

Currently, Rio de Janeiro State presents more than 20 strictly protected areas that were created independently, and together represent only about $6 \%$ of Rio de Janeiro original vegetation. It is easy to note that most of them are located in the mountains in regions with many cliffs, valleys and riverheads, as many of these were created for water source insurance and scenic beauty preservation. In fact, the most represented vegetation types in strictly protected areas are FODM (Montane Evergreen Dense Forest) and FODSM (Submontane Evergreen Dense Forest). The vegetation types not represented in any of the current strictly protected areas are FESM (Montane Semi-deciduous Forest), FESA (Aluvial Semi-deciduous Forest), SEF (Arboreous Estepic Savanna), and SEGL (Herbaceous-Arbustive Estepic Savanna).

We found a single final reserve selection solution, and the type of data (abundance based on area occupied in each cell), targets stated (with at least $30 \%$ of its total area) and rarity of some vegetation types certainly contributed to this unique result. Abundance data crossed with abundance targets turns it more difficult to find solutions with the minimum number of cells. Reserve networks solutions for biodiversity (species or vegetation types) representation using presence-absence data are generally more flexible. The representation target for the rarer vegetation types 


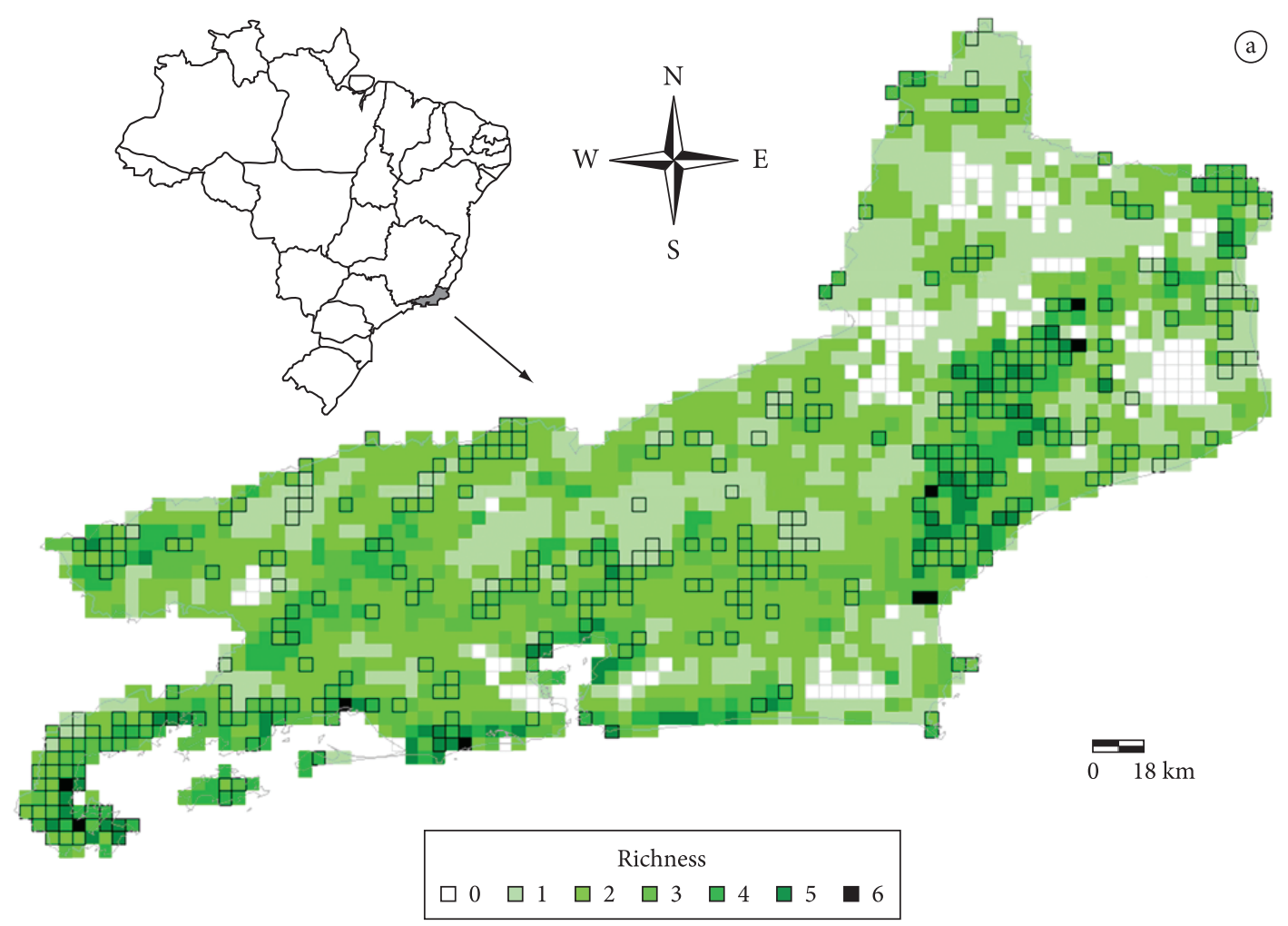

(a)

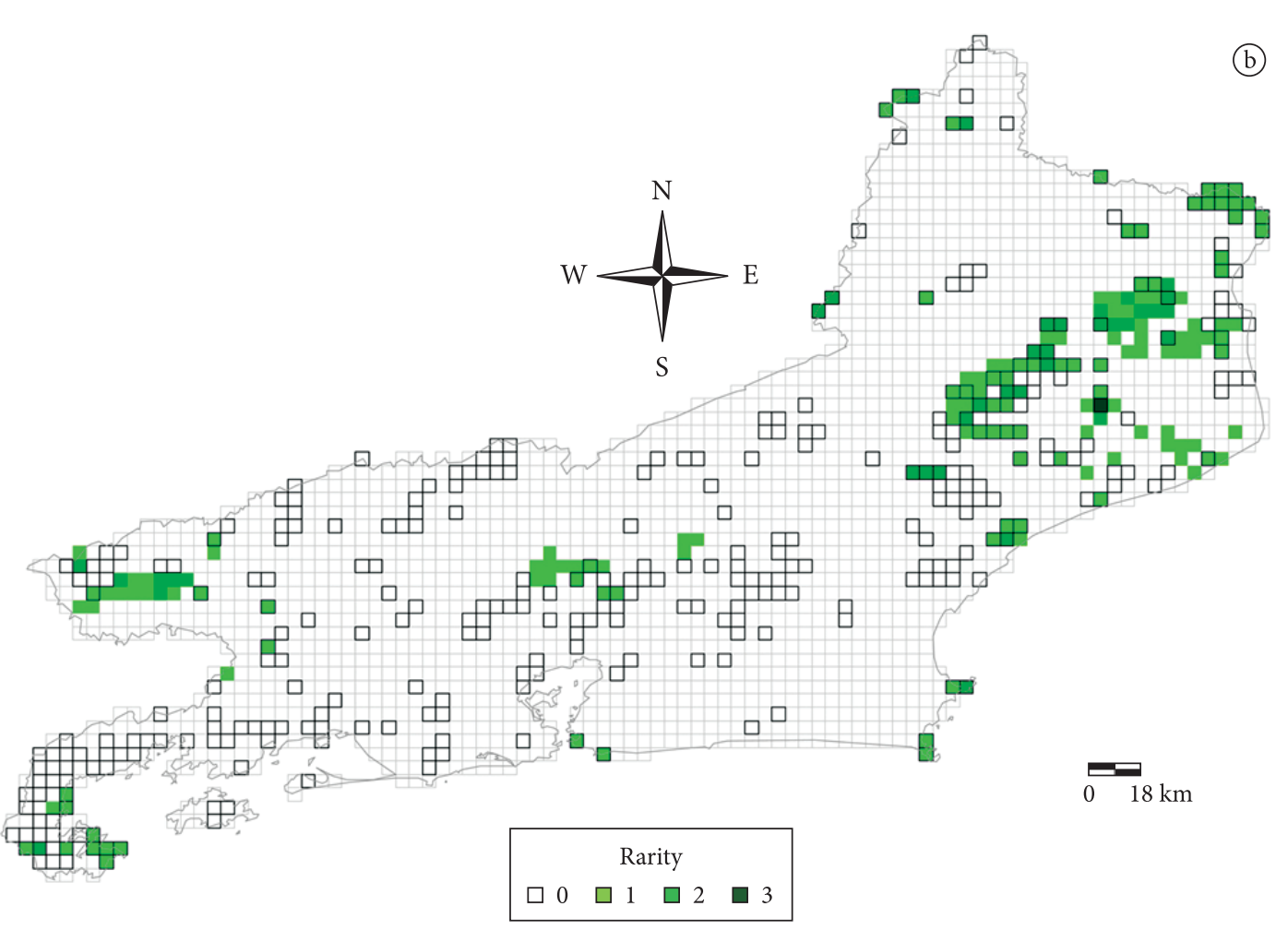

Figure 2. a) Richness pattern (number of) and b) rarity pattern (number of restricted) of the vegetation types along the 2,306 grid cells with $5 \times 5 \mathrm{~km}$ of resolution in the State of Rio de Janeiro. The cells with black outline are the ones included in the final reserve selection solution. 




Figure 3. The final reserve selection solution containing 351 cells is represented with black outline. The green polygons are current strictly protected areas (CSPA) and red polygons are priority areas indicated to be created as strictly use reserves (Brasil 2007) in the State of Rio de Janeiro.

was to represent all of them, which also restricts the final solution.

An interesting result is the role of strictly protected areas to conserve the types of vegetation in spite of the level of forest reduction. Actually forest cover in Rio de Janeiro State is scattered and fragmented in more than 10,000 remnants (most < 100 ha) (Fidalgo et al. 2009). Many cells selected are coincident with current strictly protected areas (112 of the 351 cells selected, Figure 3 ), but this study shows the urgency to increase the number of protected areas in the North and Northeast regions of Rio de Janeiro State (Figure 3). Twenty three of the 351 cells are coincident with priority areas indicated to be created as strictly use reserves by a government agency (Brasil 2007, Figure 3). In addition there is rare vegetation types (Figure $2 \mathrm{~b}$ ) not represented in the current strict use reserve system (compare Figure $2 \mathrm{~b}$ and 3 ) that are scattered along the entire state. These additional protected areas will be crucial to protect vegetation types with restrict distribution like SEF, SEGL, FESA and FODTB, all of them poorly represented in strictly protected areas network established in Rio de Janeiro State.

Curiously, analysis of reserve selection using vegetation is less common than these analyses using species data. Applying approaches based on broad filter information as land classification and vegetation units can be more advantageous from a data coverage and availability point of view. However, such strategies have been often criticized by their limited representation of endangered or threatened species requirements (Meynard et al. 2009). On the contrary, approaches based on individual species distributions are often data hungry and can be prohibitive in many regions that lack the minimum requirements of occurrence data. Furthermore, this kind of strategy have been often criticized for the biases related to sampling more common taxa and the many uncertainties related to distribution maps (Meynard et al. 2009). There is a long discussion about whether reserves selected using vegetation types represent species biodiversity data (Brooks et al. 2004). For instance, in a review of articles on reserve selection in South America, Pinto \& Grelle (2009b) found only one indexed article that uses vegetation types as target (Sarkar et al. 2004), although there are other non-indexed reserve selection studies done in Brazil (e.g. Albernaz \& Souza 2007). Anyway, vegetation data are widely available for many biomes (including Brazilian Atlantic Forest) and should also be used to perform reserve selection. In addition, analysis based on vegetation could be blended with scattered data of species geographic distribution (mainly vertebrates) to obtain more comprehensive results (see Meynard et al. 2009). A possible avenue is to improve the concept of landscape-species (see Cunha \& Grelle 2008) and adding this approach to systematic planning of this biome. 


\section{Acknowledgements}

J. A. Diniz-Filho and R. Loyola for opportunity to write this article. PNPD/CAPES, FAPERJ, CNPq for scholarship and fellowship.

\section{References}

Albernaz ALKM \& Souza MA, 2007. Planejamento sistemático para a conservação na Amazônia brasileira - uma avaliação preliminar das areas prioritárias de Macapá-99. Megadiversidade, 3:87-101.

Andelman S. et al., 1999. SITES v. 1.0: An analytical toolbox for designing ecoregional conservation portfolios. Australia: Technical Report, The Nature Conservancy.

Andrén H, 1994. Effects of habitat fragmentation on birds and mammals in landscapes with different proportions of suitable habitat: A review. Oikos, 71:355-366.

Brasil, 2007. Áreas Prioritárias para Conservação, Uso Sustentável e Repartição de Benefícios da Biodiversidade Brasileira: Atualização. Portaria MMA nº, de 23 de janeiro de 2007. Brasília: Ministério do Meio Ambiente. 574 p. (Série Biodiversidade, 31)

Brito D \& Grelle CEV, 2004. Effectiveness of a reserve network for the conservation of an endemic marsupial in Atlantic forest. Biodiversity and Conservation, 13:2519-2536.

Brito D \& Grelle CEV, 2006. Estimating minimum area of suitable habitat and viable population size for the northern muriqui (Brachyteles hypoxanthus). Biodiversity and Conservation, 15:4197-4210.

Brooks TM, Tobias J \& Balmford A, 1999. Deforestation and bird extinctions in the Atlantic forest. Animal Conservation, 2:211-222.

Brooks TM, Fonseca GAB \& Rodrigues ASL, 2004. Protected areas and species. Conservation Biology, 18:616-618.

Chiarello AG, 1999. Effects of fragmentation of the Atlantic forest on mammal communities in south-eastern Brazil. Biological Conservation, 89:71-82.

Cruz CBM et al., 2007. Classificação orientada a objetos no mapeamento dos remanescentes da cobertura vegetal do bioma Mata Atlântica, na escala 1:250.000. In Anais do XIII Simpósio Brasileiro de Sensoriamento Remoto. Florianópolis: INPE. p. 5691-5698.

Cunha AA \& Grelle CEV, 2008. Landscape-species for conservation planning: are muriquis good candidates for the Brazilian Atlantic forest? Natureza \& Conservacao, 6:125-132.

Fidalgo ECC et al., 2009. Distribuição dos remanescentes vegetais no Estado do Rio de Janeiro. In Bergallo HG et al. (eds.). Estratégias e ações para a conservação da biodiversidade no Estado do Rio de Janeiro. Rio de Janeiro: Instituto Biomas. p. 91-99.

Galindo-Leal C \& Câmara IG, 2003. The Atlantic Forest of South America: Biodiversity Status, Threats and Outlook. Washington: CABS and Island Press.
Grelle CEV et al., 2005. Prediction of threatened tetrapods based on the species-area relationship in Atlantic forest. Journal of Zoology, 265:359-364.

Grelle CEV et al., 1999. The question of scale in threat analysis: a case study with Brazilian mammals. Animal Conservation, 2:149-152.

Grelle CEV et al., 2009. Uma década de Biologia da Conservação no Brasil. Oecologia Brasiliensis, 13:418-434.

Lindenmayer D et al., 2008. A checklist for ecological management of landscape for conservation. Ecology Letters, 11:78-91.

Kirkpatrick JB, 1983. An iterative method for establishing priorities for the selection of nature reserves: an example from Tasmania. Biological Conservation, 25:127-134.

Margules CR \& Pressey RL, 2000. Systematic conservation planning. Nature, 405:243-253.

Margules CR, Nicholls AO \& Pressey RL, 1988. Selecting networks of reserves to maximise biological diversity. Biological Conservation, 43:63-76.

Meynard CN, Howell CA \& Quinn JF, 2009. Comparing alternative systematic conservation planning strategies against a politically driven conservation plan. Biodiversity and Conservation, 18:3061-3083.

Metzger JP et al., 2009. Time-lag in biological responses to landscape changes in a highly dynamic Atlantic forest region. Biological Conservation, 142:1166-1177.

Myers N et al., 2000. Biodiversity hotspots for conservation priorities. Nature, 403:853-858.

Paglia AP et al., 2004. Lacunas de conservação e áreas insubstituíveis para vertebrados ameaçados da Mata Atlântica. In Anais do IV Congresso Brasileiro de Unidades de Conservação; Curitiba.

Pardini R et al., 2005. The role of forest structure, fragment size and corridors in maintaining small mammal abundance and diversity in an Atlantic Forest landscape. Biological Conservation, 124:253-266.

Pinto LP, Bebê L, Paese A, Fonseca M, Paglia A \& Lamas I, 2006. Mata Atlântica Brasileira: Os desafios para a conservação da biodiversidade de um hotspot mundial. In: Rocha CFD, Bergallo HG, van Sluys M \& Alves MAS (eds). Biologia da Conservação: Essências. Rio de Janeiro: Ed. Rima, p. 91-11.

Pinto MP \& Grelle CEV, 2009a. Reserve selection and persistence: Complementing the existing Atlantic Forest reserve system. Biodiversity and Conservation, 18:957-968.

Pinto MP \& Grelle CEV, 2009b. Seleção de Reservas: Estudos na América do Sul e revisão dos conceitos. Oecologia Brasiliensis, 13:444-464.

Pires AS et al., 2002. Frequency of movements of small mammals among Atlantic Coastal Forest fragments in Brazil. Biological Conservation, 108:229-237.

Possingham H, Ball I \& Andelman S, 2000. Mathematical methods for identifying representative reserve networks. In Ferson S \& Burgman M (eds.), Quantitative methods for conservation biology. New York: Springer. p. 291-306. 
Possingham HP et al., 2006. Protected Areas: Goals, Limitations, and Design. In Groom MJ, Meffe GK \& Carroll CR. (eds.). Principles of Conservation Biology. Sunderland: Sinauer Associates. p. 509-533.

Pressey RL \& Bottrill M, 2009. Approaches to landscape- and seascape - scale conservation planning: convergence, contrasts and challenges. Oryx, 43:464-475.

Pressey RL et al., 1993. Beyond opportunism: key principles for systematic reserve selection. Trends in Ecology and Evolution, 8:124-128.

Ribeiro MC, Metzger JP, Martensen AC, Ponzoni FJ \& Hirota MM, 2009. Brazilian Atlantic Forest: How much is left and how is the remaining forest distributed? Implications for conservation. Biological Conservation, 142:1141-1153.

Rocha CFD et al., 2006. Corredores Ecológicos e Conservação da Biodiversidade: Um estudo de caso na Mata Atlântica. In Rocha CFD et al. (eds.). Biologia da Conservação: Essências. São Carlos: Rima Editora. p. 327-342.

Sarkar S et al., 2004. Place prioritization for biodiversity conservation using probabilistic surrogate distribution data. Diversity and Distributions, 10:125-133.
Silva JMC \& Casteleti CHM, 2003. Status of the biodiversity of the Atlantic Forest of Brazil. In Galindo-Leal C \& Câmara IG (eds.). The Atlantic Forest of South America: Biodiversity Status, Threats, and Outlook. Washington: CABS and Island Press. p. 43-59.

Vane-Wright RI, Humphries CJ \& Williams PH, 1991. What to protect? Systematics and the agony of choice. Biological Conservation, 55:235-254.

Veloso HP, 1992. Sistema Fitogeográfico. In IBGE. Manual técnico da vegetação brasileira. 1 ed. Rio de Janeiro: Instituto Brasileiro de Geografia e Estatística. p. 9-38. (Manuais Técnicos em Geociências).

Vicente RF, Vanzela ALL \& Torezan JMD, 2009. Representatividade de Ecossistemas no Sistema de Unidades de Conservação no Estado do Paraná, Brasil. Natureza \& Conservaçao, 7:50-66.

Vieira MV et al., 2009. Land use vs. fragment size and isolation as determinants of small mammal composition and richness in Atlantic Forest remnants. Biological Conservation, 142:1191-1200.

Received: February 2010

First Decision: March 2010

Accepted: April 2010 